\title{
Eksplorasi Material Semen untuk Pengembangan Produk Elemen Estetik
}

\author{
I Ketut Suarna \\ Program Studi Desain Interior, Institut Teknologi Sains Bandung \\ E-mail: suarnatp@gmail.com
}

Informasi naskah:

Diterima

1 Juli 2020

Direvisi

16 Agustus 2020

Disetujui terbit

20 Agustus 2020

Diterbitkan

31 Agustus 2020

\begin{abstract}
Abstrack
Cement is a unique material, initially as the base material with the main function as an adhesive for other materials whose existence is always covered. Nowdays, the application of cement materials in interior elements appears to be more honest. Natural ash color and cement characteristics are interesting things to be exposed. The use of cement material has also grown not only limited to the elements that make up space (floors, walls and ceilings), but has stepped into space facilities (furniture) and aesthetic elements. Through a series of experiments with the "design by doing" method, experiments were carried out by giving chemical treatments such as foam agents, adding magnesium carbonate powder and adding magnesium oxide to the base materials (cement, cement + sand) to explore and discover various potentials, uniqueness, peculiarities and lighter feature as new ideas in aesthetic elements product development in interior design. The results obtained from a series of experiments showed differences in the cement concrete characteristics through its texture, shape, number and size of pores and difference in weight .
\end{abstract}

Keywords: cement material, chemical treatments, characteristics

\section{PENDAHULUAN}

\subsection{Latar Belakang}

Semen merupakan bahan perekat yang tersusun dari unsur batu kapur (Cao), tanah liat yang mengandung $\mathrm{SiO} 2, \mathrm{Al} 2 \mathrm{O} 3$ dan $\mathrm{Fe} 2 \mathrm{O} 3$, pasir kwarsa atau batu silica, dan pasir besi. ${ }^{1)}$ Pada pekerjaan konstruksi, umumnya semen dipergunakan sebagai perekat antara batu penyusun pondasi, dengan campuran pasir dan agregat lainnya membentuk beton sebagai struktur bangunan, serta perekat pada material penyusun dinding konvensional. Mulanya, keberadaan semen justru ditutupi dengan material lain, sebagai contoh plester dan acian pada dinding mendapat perlakuan plamir dan cat dinding, wall paper atau ditutup material lain. 
Wacana sustainable design, yang berorientasi pada keseimbangan ekologi, sosial dan ekonomi ${ }^{2)}$ menjadi isu penting untuk direspon desainer. Victor Papanek menekankan aspek ekologi pada penerapan metode/alat, material, proses penggunaan, kebutuhan serta keberlangsungan ${ }^{3)}$. Terkait ekologi dan material, O’brien, M. dan Palermini, D. merumuskan efesiensi energi, efesiensi material, ukuran dan bentuk bangunan, struktur serta konstruks ${ }^{4)}$. Aplikasi material semen ekspose pada interior desain memangkas beberapa proses kerja menjadi lebih singkat dan lebih efesien. Penerapan sebagai dinding ekspose, dapat menghilangkan proses plamir dan pengecatan dinding, aplikasi semen ekspose menjadi salah satu alternatif dalam mengurangi penggunaan material kayu, meniadakan cover HPL, plywood dan finishing politur, menghilangkan cover granite ataupun marmer yang tentunya memangkas proses kerja, waktu dan budgeting proyek. Potensi warna abu natural serta permukaan yang tidak rata dari material semen justru ditampilkan secara polos ${ }^{5)}$, jujur tanpa balutan lagi.

Penggunaan material semen tidak terbatas pada elemen lantai dan dinding, bahkan berkembang kepada fungsi fasilitas ruang. Material semen diaplikasikan sebagai furniture, seperti tempat tidur, meja nakas, bench, kitchen set, bahkan merambah pada fasilitas mandi seperti bathtub, wastafel sampai aksesoris berupa tempat sabun, samphoo, vas bunga, tempat lilin serta elemen dekorasi.
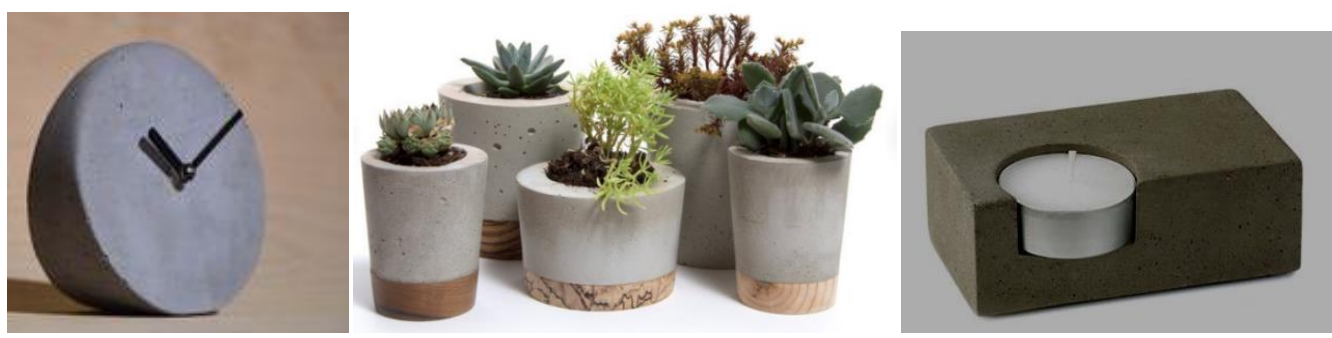

Gambar 1. Beberapa contoh elemen estetik dengan material semen ekspose

Sumber: (1)mohawork.com, (2) etsy.com, (3) adamchristoperdesign.com

Pemamahaman akan desain tidak terhenti pada wujud fisik atau produk-produk sebagai wujud aplikasinya saja. Desain merupakan proses panjang dari memecahkan suatu permasalahan, menemukan solusi, melakukan perbaikan, meningkatkan kualitas hidup, melalui proses, tindakan, pemikiran yang dilandasi oleh kegiatan manusia. Untuk itu salah satu upaya untuk memahani proses desain adalah melalui pendekatan eklsporasi material. Pemikiran tentang material terkait pada bahan baku dan proses ${ }^{6}$ ). Eksperimen sebagai upaya menemukan berbagai potensi kebaruan biasanya memiliki tujuan tetapi juga terkadang abstrak. Pendekatan eksperimental dengan material akan memberi peluang untuk gagasan yang benar-benar inovatif ${ }^{7)}$. 


\subsection{Rumusan Masalah}

Pendekatan desain melalui elemen material dapat dilakukan dengan dua cara. Yang pertama dengan cara menetapkan fungsi dan gagasan terlebih dahulu, dilanjutkan dengan menyesuaikan material yang dapat menunjang fungsi dan desainnya. Cara yang kedua adalah kebalikannya, diawali dari eksplorasi material selanjutnya mengadopsi kegunaannya ${ }^{8}$. Sebagai langkah awal eksperimen, peneliti tidak harus terburu-buru mengambil keputusan desain. Berbagai karakter visual yang ditemukan dikembangkan lagi ke dalam gagasan-gagasan baru. Pada prinsipnya menemukan potensi material menjadi hal yang penting dari penelitian ini.

\subsection{Tujuan dan Manfaat Penelitian}

Melalui serangkaian eksperimen dengan memberi perlakuan, penelitian awal eksplorasi material semen ini bertujuan untuk:

1. Menggali berbagai potensi yang dimiliki material semen dalam upaya menemukan /gagasan-gagasan baru.

2. Menginvestigasi material semen untuk menemukan keunggulannya.

3. Memahami karakteristik material dan kemungkinanan pengembangannya.

4. Menemukan karakater beton semen yang lebih ringan sebagai upaya meminimumkan harga jual ketika sudah dijadikan suatu produk.

\subsection{Batasan Penelitian}

Pada umumnya eksplorasi material dengan memberi perlakuan diklasifikasikan ke dalam dua jenis perlakuan, yaitu perlakuan fisik dan perlakuan kimiawi. Memotong, menyayat, merobek, menempa, melipat dikategorikan ke dalam perlakuan fisik. Sementara dalam penelitian ini eksplorasi material semen akan diberi perlakuan kimiawi dengan menambahkan foam agent, magnesium carbonate dan magnesium oxide. Dampak perlakuan kiamiawi ini menjadi obyek yang diamati untuk mendapatkan berbagai kemungkinan pengembangannya.

\subsection{Manfaat Penelitian}

1. Karakter visual yang diperoleh dari serangkaian eksperimen dapat memberi peluang dan gagasan-gagasan baru dalam pengembangan produk.

2. Hasil evaluasi dan eksperimen ini dapat menjadi pengetahuan dan pertimbangan penelitian lanjutan.

\section{METODE PENELITIAN}

\subsection{Pendekatan Penelitian}

Penelitian ini merupakan penelitian eksperimen dengan memberi perlakuan kimiawi berupa foam agent, magnesium carbonate, dan magnesium oxide pada material dasar (semen atau semen + pasir). Respon dari material dasar terhadap karakter visualnya dapat dijadikan acuan dan pertimbangan dalam pengembangan selanjutnya Melalui pendekatan 
“design by doing" metode yang mengandalkan sikap bekerja, mencoba atau melakukan, maka karakteristik yang dihasilkan merupakan akibat yang ditangkap secara visual bukan merupakan bentuk atau fungsi yang telah direncanakan sebelumnya.

\subsection{Prosedur Penelitian}

1. Klasifikasi material dasar. Semen merupakan material yang disusun dari material alami dalam bentuk bubuk yang dalam pengolahannya dilunakkan terlebih dahulu dengan air sebelum terjadinya pengerasan kembali. Dalam penelitian ini, material dasar yang yang diujikan adalah semen jenis Portland (yang umum dipasaran) dan semen dengan campuran material pasir.

2. Proses pelunakan, pencampuran dan perlakuan kimiawi membutuhkan alat-alat bantu seperti berbagai wadah materi yang dicampurkan, alat untuk mencampur seperti kinerja mixer, serta alat-alat bantu dalam proses pencetakan dan pengeringan.

3. Berbagai karakteristik visual yang dihasilkan dari perlakuan kimiawi menjadi hal yang perlu dipahami potensi dan kemungkinanan pengembangannya dalam menemukan keunikan, kekhasan dan kebaruan

\subsection{Spesifikasi Peralatan dan Material}

Peralatan dan material yang akan digunakan terkait dengan eksperimen penelitian adalah sebagai berikut:

1. Semen dan material pendukung seperti pasir adalah material dasar yang akan diberi perlakuan kimiawi untuk mengungkap berbagai potensi yang dimiliki.

2. Foam Agent (busa), magnesium carbonate, magnesium oxide, adalah unsur yang menjadi perlakuan (stimulus) pada material dasar. Respon material dasar terhadap perlakuan ini menjadi obyek pengamatan yang perlu dicatat setiap karakter yang muncul.

3. Timbangan elektrik, adalah alat untuk membantu dalam mengetahui komposisi setiap material yang akan diujikan.

4. Bor dan mata pengaduknya merupakan alat bantu dalam proses pelunakan (penyempurnakan adonan).

5. Peralatan pendukung lainnya berupa wadah adonan dan perlengkapan dalam proses cetak dan pengeringan.

\section{PEMBAHASAN DAN DISKUSI}

\subsection{Tahap Eksperimen}

1. Kelompok pertama dengan material dasar semen Portland Tiga Roda. Adonan akan dibagi empat, yaitu adonan 1 (semen saja), adonan 2 (semen + foam agent), adonan 3 $($ semen + foam agent + magnesium carbonate $)$ dan adonan $4($ semen + foam agent + magnesium oxide).

2. Kelompok kedua, dengan material dasar semen dicampur pasir hitam yang sudah diayak. Kelompok ini dibagi lagi menjadi empat yaitu adonan 5 (semen + pasir), 
adonan 6 (semen + pasir + foam agent), adonan 7 (semen + pasir + foam agent + magnesium carbonate), adonan 8 (semen + pasir + foam agent + magnesium oxide).

Pada adonan 1 dan adonan 5, material dasar diaduk dengan mata bor pengaduk kemudian dilunakkan dengan air dan dicetak. Penggunaan foam agent dilakukan dengan menambahkan air lalu mengaduknya sehingga menghasilkan busa yang dicampur dengan material dasar atau stimulus lainnya. Semua item adonan dicetak dalam cetakan plastik berukuran $7 \mathrm{~cm} \mathrm{x} 7 \mathrm{~cm} \times 3 \mathrm{~cm}$.

\subsection{Perbandingan Hasil}

Berikut visualisasi setelah pengeringan secara alami setelah 7 hari

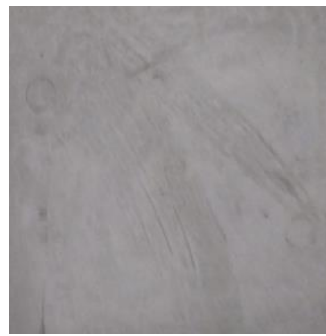

Adonan 1 (semen saja)

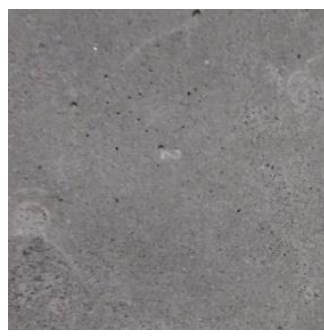

Adonan 5 $($ semen + pasir $)$

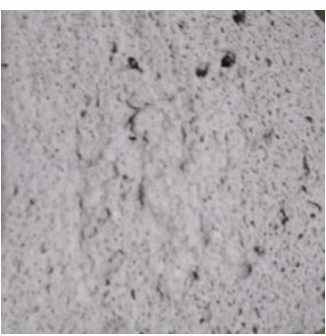

Adonan 2 (semen + foam agent)

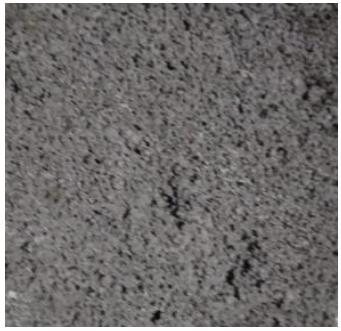

Adonan 6
(semen + pasir
+form aosnt)

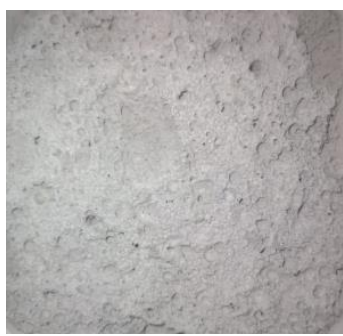

Adonan 3 (semen + foam agent + magnesium carbonate)

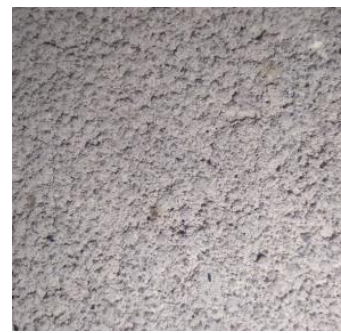

Adonan 7

(semen + pasir +foam agent + magnesium carbonate)

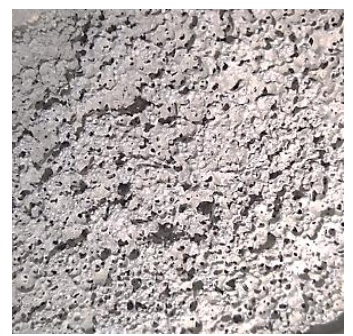

Adonan 4 (semen + foam agent + magnesium oxide)

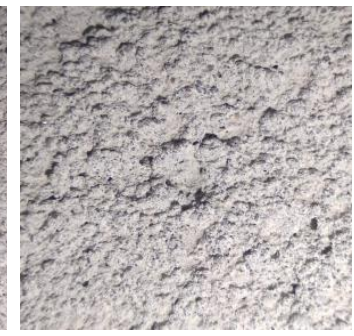

Adonan 8

$($ semen + pasir + foam agent + magnesium oxide)

Gambar 2. Visualisasi perbandingan perlakuan kimia terhadap material semen

Delapan adonan menunjukkan perbedaan karakter secara visual,

1. Karakter tekstur.

Adonan 1 dan adonan 5 memiliki permukaan yang rata. Penggunaan foam agent menghasilkan cetakan yang berpori sehingga adonan 2, 3, 4, 6, 7, dan 8 memiliki permukaan tidak rata. Penambahan magnesium carbonate dan magnesium oxide juga memberi efek rongga pada beton semen yang dihasilkan terutama terlihat pada material dasar semen saja (adonan 3 dan 4).

2. Pori-pori.

Adonan 1 tidak terlihat berpori, sementara adonan 5 menunjukkan pori-pori halus. Penambahan foam agent (busa) memberi efek pori pada beton semen yan dicetak. Poripori pada kelompok dengan material semen menghasilkan beton cetak yang lebih 
berongga terutama pada adonan yang ditambah magnesium carbonate dan magnesium oxide.

3. Perbedaan berat.

Penambahan foam agent menghasilkan beton semen berpori yang berpengaruh pada berat adonan. Adonan 1 dengan material dasar semen saja menjadi adonan yang memilki beban paling berat. Penambahan foam agent pada kelompok dengan material dasar semen saja lebih ringan dari pada kelompok yang berbahan dasar semen dan pasir. Demikian juga penambahan foam agent, magnesium carbonate dan magnesium oxide pada adonan 3 dan 4 menghasilkan beton semen yang ringan.

\section{KESIMPULAN}

Perlakuan kimia terhadap materi dasar (semen dan pasir) menghasilkan karakter visual yang berbeda, dapat diamati dari perbedaan tekstur, bentuk, ukuran dan sebaran pori-pori yang dihasilkan. Begitu juga terhadap beratnya, dalam ukuran yang dicetak sama perbandingan ukuran beratnya menunjukkan perbedaan antara satu adonan dengan yang lainnya. Walaupun secara visual sudah memberi gambaran berbeda antara adonan satu dengan lainnya, namun penambahan magnesium carbonate dan magnesium oxide menghasilkan beton semen yang lebih rapuh dari adonan lainnya.

\section{UCAPAN TERIMAKASIH}

Penulis mengucapkan terimakasih kepada LPPM Institut Teknologi Sains Bandung dan Yayasan Institut Teknologi Sains Bandung yang telah memberi kesempatan penelitian awal ini.

\section{DAFTAR PUSTAKA}

1) http://www.sementigaroda.com. Diunduh pada tanggal 13 Agustus 2019.

2) Kusumarini, Yusita. (2015). Konstruksi Teori Sustainable Interior Design: Pendekatan Holistik Eco-Socio-Econo Interior Design Kontektual di Indonesia, Surabaya: Institut Teknologi Sepuluh November.

3) Papanek, Victor. (2011). Human Ecology and Social Change, London: Granada Publishing.

4) O'Brien, M and Palermini, D. (1993). Guide to Resourse Efficient Building with Value, Resourse-Efficient Construction Conference and Trade Show, Portland, USA.

5) Akmal, Imelda. (2008). Eksploasi Semen, Rumah Ide, Jakarta: Gramedia.

6) Bramston, D. (2009). Material Throught, Laussane: AVA Publishing SA.

7) Bramston, D. (2009). Basics Product Design, Laussane: AVA Publishing SA.

8) Masry, Andri (2009). Eksplorasi Material, Metode Pendekatan pada Disiplin Desain untuk Mencari Kebaruan, Bandung: Itenas. 